\title{
TINDAK PIDANA KORUPSI DALAM PERUNDANG-UNDANGAN DI INDONESIA
}

\author{
Andi Samsan Nganro
}

\begin{abstract}
The changing of 'UU' is intended to guarentee the law, to avoid the different law interpretation and to give protection to the economic and social right. The latets, UU' no. 20 th. 2001 which is known as the changing of UU no. 31 th. 1999 is about corruption demolisbing.
\end{abstract}

Kata kunci: tindak pidana, korupsi, pemberantasan tindak. pidana korupsi.

\section{A. Pendahuluan}

Pada waktu Undang Undang Nomor 3 Tahun 1971 tentang Tindak Pidana Korupsi diundangkan pada tanggal 29 Maret 1971, berbagai harapan diungkapkan agar undang-undang tersebut menjadi sarana yang efektif dalam pemberantasan tindak pidana korupsi. Ternyata apa yang diharapkan dengan kelahiran Undang Undang Nomor 3 Tahun 1971 dalam perjalanan waktu masih belum dapat memenuhi harapan, karena dipandang sudah tidak sesuai lagi dengan

'Ketua Pengadilan Negeri Jakarta Selatan. Makalah ini pernah disampaikan pada Pelatiban bagi Calon Hakim Ad Hoc Tindak Pidana Korupsi (TIPIKOR) untuk Pengadilan Tingkat Pertama, Tingkeat Banding dan Tingkat Kasasi Tabun 2006 yang diselenggarakan oleh Pusdiklat Mabkeamah Agung RI, pada tanggal 25 April 2006, bertempat di Pusdiklat Biro Pusat Statistik Jl. Raya Jaga Karsa No. 70. Jakarta. 


\section{Andi Samsan Nganro}

perkembangan kebutuhan hukum. Bahkan ada anggapan bahwa tidak efektifnya pemberantasan korupsi dalam kurun waktu sempurna undang-undangnya.

Memasuki era reformasi, pada tanggal 16 Agustus 1999 diundangkanlah Undang Undang Nomor 31 Tahun 1999 tentang Pemberantasan Tindak Pidana Korupsi menggantikan Undang Undang Nomor 3 Tahun 1971. Dalam penjelasan umum Undang Undang Nomor 31 Tahun 1999 ditegaskan, bahwa undang-undang ini diharapkan mampu memenuhi dan mengantisipasi perkembangan kebutuhan hukum masyarakat dalam rangka mencegah dan memberantas secara lebih efektif setiap bentuk tindak pidana korupsi yang sangat merugikan keuangan negara maupun perekonomian negara pada khususnya serta masyarakat pada umumnya.

Dari aspek nilai, Undang Undang Nomor 31 Tahun 1999 memiliki beberapa nilai tambah jika dibandingkan dengan Undang Undang Nomor 3 Tahun 1971, antara lain:

1. Dalam kaitannya dengan partisipasi publik, untuk membantu upaya pencegahan dan pemberantasan tindak pidana korupsi, penerapan sistem pembuktian terbalik secara terbatas;

2. Kemudahan untuk membuka kerahasiaan bank tentang keadaan keuangan tersangka/terdakwa tanpa harus meminta izin terlebih dahulu kepada Menteri Keuangan RI; dan

3. Mengatur tentang ancaman pidana minimum khusus, pidana denda yang lebih tinggi, dan ancaman pidana mati serta pembentukan Komisi Pemberantasan Tindak Pidana Korupsi (KPK).

4. Peran serta masyarakat dengan reward system dan dengan rincian tentang perlindungan hukum.

Bahwa tindak pidana korupsi yang terjadi secara meluas, tidak hanya merugikan keuangan negara tetapi juga telah merupakan pelanggaran terhadap hak-hak sosial dan ekonomi masyarakat secara luas, sehingga tindak pidana korupsi perlu digolongkan sebagai 
kejahatan yang pemberantasannya harus dilakukan secara luar biasa. Di samping itu, untuk lebih menjamin kepastian hukum, menghindari keragaman penafsiran hukum dan memberikan perlindungan terhadap hak-hak sosial dan ekonomi masyarakat serta perlakuan secara adil dalam memberantas tindak pidana korupsi, maka perlu diadakan perubahan atas Undang Undang Nomor 31 Tahun 1999 yang dikenal dengan Undang Undang Nomor 20 Tahun 2001 tentang Perubahan atas Undang Undang Nomor 31 Tahun 1999 tentang Pemberantasan Tindak Pidana Korupsi.

\section{B. Perubahan Perumusan Delik}

Undang Undang Nomor 3 Tahun 1971 apabila dibandingkan dengan Undang Undang Nomor 31 Tahun 1999 yang diubah dan ditambah dengan Undang-undang Nomor 21 Tahun 2001, maka salah satu perubahannya adalah perubahan rumusan delik.

Rumusan delik yang termuat dalam Undang Undang Nomor 3 Tahun 1971 hanya tujuh (7) pasal dari dua puluh enam (26) pasal yang ada dalam undang-undang tersebut. Ketujuh pasal tersebut adalah pasal 1 ayat (1) sub a, b, d, dan e; pasal-pasal 29, 30, dan 31. Tetapi untuk pasal 29 sampai dengan pasal 31 tidak berkenaan dengan korupsi dalam arti material dan keuangan, hanya mengenai perbuatan yang mempersulit pemeriksaan perkara korupsi pada tingkat penyidikan, penuntutan, dan pemeriksaan di muka persidangan pengadilan. Dengan demikian, Korupsi dalam arti material dan keuangan terdapat hanya dalam empat rumusan, yaitu sub a, b, d, dan e dalam pasal 1 ayat (1). Sedangkan rumusan yang tercantum dalam pasal 1 ayat (1) sub c adalah penarikan tiga belas (13) pasal dari Kitab Undang Undang Hukum Pidana (KUHP).

Pasal 1 ayat (1) sub a Undang Undang Nomor 3 Tahun 1971, berubah menjadi pasal 2 Undang Undang Nomor 31 Tahun 1999 dengan beberapa perubahan redaksi. Begitu pula rumusan pasal 1 ayat (1) sub b Undang Undang Nomor 3 Tahun 1971 menjadi pasal 3 Undang Undang Nomor 31 Tahun 1999. Pasal 1 ayat (1) sub d 


\section{Andi Samsan Nganro}

Undang Undang Nomor 3 Tahun 1971 menjadi pasal 13 Undang Undang Nomor 31 Tahun 1999 jo Undang Undang Nomor 21 Tahun 2001. Pasal 1 ayat (1) sub e Undang Undang Nomor 3 Tahun 1971 dihapus karena tidak logis, seseorang yang telab melakukan perbuatan korupsi melaporkan diri dan apabila tidak melapor akan merupakan delik tersendiri. Dalam realitas tidak pernah ada orang yang dituntut berdasarkan pasal 1 ayat (1) sub e Undang Undang Nomor 3 Tahun 1971.

Dalam perumusan pasal 2 dan 3 Undang Undang Nomor 31 Tahun 1999 yang berasal dari pasal 1 ayat (1) sub a dan b Undang Undang Nomor 3 Tahun 1971, perkataan langsung atau tidak langsung merugikan.......dst, dihapus karena dalam hukum pidana Indonesia hanya mengenal "akibat yang langsung". Jika dipakai akibat "tidak langsung", berarti menganut teori von Buri mengenai teori kauslitas yang conditio sine qua non, yang menyatakan "semua sebab atau faktor terjadinya akibat adalah sebab" di mana Indonesia dan Belanda menganut teori Trager atau von Kries, yang menyatakan bahwa yang menjadi sebab ialab yang seimbang (adequaat) dengan akibat. Jadi, berdasarkan teori ini sebab yang tidak langsung tidak dapat diterima. ${ }^{1}$

Kalimat lain yang dihapus ialah "atau patut diketabui..." di dalam pasal 1 ayat (1) sub a Undang Undang Nomor 3 Tahun 1971 menjadi pasal 2 Undang Undang Nomor 31 Tahun 1999, karena kalimat "atau patut diketabui..." berarti culpa yang berarti kerugian negara yang timbul dapat terjadi karena kelalaian. Dengan dihapuskannya kalimat "atau patut diketabui...", berarti kerugian negara yang terjadi harus dilakukan dengan sengaja.

Rumusan lain yang berubah dari delik materil pada pasal 1 ayat (1) sub a Undang Undang Nomor 3 Tahun 1971 menjadi delik formal pasal 2 Undang Undang Nomor 31 Tahun 1999 dengan disisipkannya kalimat "dapat merugikan keuangan negara atau perekonomian negara”. Artinya, tidak perlu benar-benar telah terjadi kerugian keuangan Negara, dengan "dapat” atau mungkin menimbul-

${ }^{1}$ Andi Hamzah, Pemberantasan Konupsi melalui Huleum Pidana Nasional dan Internasional, (Jakarta: PT Raja Grafindo Persada, 2004), hal. 107-108 
kan kerugian negara atau perekonomian negara, maka unsur delik ini telah terpenuhi.

Dalam prakteknya, pasal-pasal yang paling sering dipergunakan dalam menuntut perkara korupsi di pengadilan adalah dakwaan berdasarkan pasal 2 dan atau pasal 3 Undang Undang Nomor 31 Tahun 1999 jo Undang Undang Nomor 21 Tahun 2001 (pasal 1 ayat (1) sub a dan b Undang Undang Nomor 3 Tahun 1971), dengan konstruksi dakwaan secara alternatif/subsidaritas yaitu ; dakwaan primair dan subsider.

Pasal 2 ayat (1) Undang Undang Nomor 31 Tahun 1999 berbunyi: "setiap orang yang secara melawan hukum perbuatan memperkaya diri sendiri atau orang lain atau suatu korporasi yang dapat merugikan keuangan negara atau perekonomian negara, dipidana ...."

Bagian inti atau unsur (bestanddelen) yang termuat dalam pasal 2 ini adalah :

1. Melawan hukum;

2. Memperkaya diri sendiri atau orang lain atau korporasi; dan

3. Dapat merugikan keuangan negara atau perekonomian negara.

\section{Beberapa Aspek Pidana Korupsi}

\section{Melawan Hukum (Wedderecbtelijk)}

Sebagaimana diketahui, bahwa setiap delik — termasuk delik korupsi- selalu mengandung sifat melawan hukum (wedderechtelijk). Jika melawan bukum itu disebut secara tegas dalam rumusan delik, maka melawan bukum tersebut merupakan unsur/bagian inti (bestanddelen). Konsekuensinya, adanya keharusan mencantumkan unsur melawan hukum itu dalam surat dakwaan, dan harus pula membuktikan telah dilakukannya perbuatan melawan hukum. Jika perbuatan melawan hukum itu tidak tercantum secara tegas dalam rumusan delik, maka sifat melawan hukum itu tetap ada sebagai unsur yang tersirat (diam-diam). Hanya saja tidaklah perlu mencantumkan unsur melawan hukum dalam surat dakwaan, begitu pula dalam 


\section{Andi Samsan Nganro}

requisitoir tidak perlu membuktikan telah dilakukannya perbuatan melawan hukum oleh terdakwa, namun terdakwa atau penasehat hukumnya diberi kesempatan untuk membuktikan bahwa terdakwa tidak melawan hukum.

Pengertian melawan hukum menurut Undang Undang Nomor 31 Tahun 1999 jo Undang Undang No. 21 Tahun 2001 meliputi pengertian formil dan materil. Melawan hukum dalam arti formil dan arti materil yaitu, meskipun perbuatan tersebut tidak diatur dalam perundang-undangan, namun apabila perbuatan tersebut tercela karena tidak sesuai dengan rasa keadilan atau norma-norma kehidupan sosial dalam masyarakat, maka perbuatan tersebut dapat dipidana.

Maksud dengan melawan hukum dalam arti formil, ialah apabila suatu perbuatan telah memenuhi rumusan undang-undang atau unsur delik dengan sendirinya dianggap perbuatan itu telah melawan hukum. Pengertian melawan hukum dalam arti materil ialah bukan saja perbuatan yang bertentangan dengan undang-undang, tetapi juga perbuatan itu bertentangan dengan kepatutan atau kelaziman di dalam pergaulan atau norma-norma sosial dalam masyarakat. Pengertian melawan hukum dalam arti materil ini, mendapat pengaruh yang kuat dari ajaran perbuatan melanggar hukum (onrechtmatige daad) sehingga ada kecenderungan pandangan, seperti yang dikatakan oleh Pompe, yaitu pengertiannya sama dengan onrecbtmatige daad di dalam hukum perdata melalui Arrest Coben-L indenbaum tanggal 31 januari 1919.

Dalam perkembangan hukum pidana (korupsi), ajaran perbuatan melawan hukum materil dibatasi penggunaannya melalui fungsi negatif sebagai dasar pembenar (tak tertulis). Ini dimaksudkan untuk menghindari pelanggaran asas legalitas dan penggunaan analogi yang dilarang dalam hukum pidana. Penerapan ajaran melawan hukum materil melalui fungsi negatif dimaksudkan bahwa meskipun terdakwa memenuhi rumusan delik sehingga perbuatannya adalah melanggar hukum secara formil, namun apabila dilihat dari isinya ternyata perbuatannya tidak melawan hukum secara materil, sehingga diartikan bahwa masyarakat tidak memandang perbuatannya itu tercela, maka terhadapnya tidak dikenakan pidana. 
Tindak Pidana Korupsi dalam Perundang-undangan Indonesia

Yurispudensi Mahkamah Agung RI yang menerapkan sifat melawan hukum materil melalui fungsi negatif, antara lain :

1. Putusan Mahkamah Agung RI No. $81 \mathrm{~K} / \mathrm{Kr} / 1973$, tertanggal 30 Maret 1977 dalam perkara Ir. Otjo Danaatmadja antara lain dipertimbangkan asas materiele wederrechtelijkbeid yang mengandung suatu pengertian tentang wederrechtelijkeid yang diartikan secara materil menurut isinya dan memegang peranan negatif dalam pengertian bahwa suatu perbuatan tidak dapat dipidana apabila tidak terdapat asas materiele wederrechtelikbeid dan materiele wederrecbtelijk walaupun formal adalah wederrecbtelijk karena memenuhi segala unsur dari suatu tindak pidana. Konsekuensi pengakuan fungsi negatif dari perbuatan melawan hukum secara materil, maka terdakwa meskipun perbuatannya telah memenuhi rumusan delik tetapi perbuatannya dipandang tidak melawan hukum secara materil karena ternyata terdakwa tidak mengambil keuntungan, terdakwa melayani kepentingan umum dan negara tidak dirugikan. Dengan demikian, ada dasar pembenar yang tidak tertulis sehingga terdakwa dilepas dari segala tuntutan hukum.

2. Putusan Mahkanmah Agung RI No. $42 \mathrm{~K} / \mathrm{Kr} / 1965$, tertanggal 8 Januari 1966 dalam perkara Machroes Effendi.

Penerapan ajaran perbuatan melawan hukum secara materil dengan fungsi negatif dalam perkembangannya terjadi pergeseran ke arah fungsi positif ketika hakim menghadapi perbuatan-perbuatan yang semula hubungan hukumnya bersifat keperdataan, namun akibatnya telah menimbulkan dugaan kerugian negara yang cukup besar sehingga perbuatan itu menjadi samar-samar antara kasus perdata dan kasus pidana. Begitu pula dengan perbuatan-perbuatan yang mempunyai tipologi baru dalam dimensi perekonomian Indonesia, dimana masyarakat menilai perbuatan itu sebagai koruptif dan tercela sehingga merugikan masyarakat/negara. Tetapi perbuatannya ternyata tidak memenuhi rumusan undang-undang yang bersanksi pidana. 


\section{Andi Samsan Nganro}

Menurut Indriyanto Seno Adjie, penerapan fungsi positif dari hukum materil dapat diterapkan dengan kriteria yang sangat ketat dan limitatif serta kasuistis, yaitu apabila perbuatan pelaku yang tidak termasuk atau tidak memenuhi rumusan delik, dipandang dari segi kepentingan hukum, ternyata menimbulkan kerugian yang sangat besar dan kurang seimbang bagi masyarakat/negara dibandingkan dengan keuntungan yang disebabkan perbuatan pelaku yang tidak memenuhi rumusan delik tersebut. Untuk itu, menurut Indriyanto diperlukan suatu terobosan dari hakim untuk menghukum si pelaku yang meskipun perbuatannya secara formil tidak melawan hukum, tetapi secara materil terbukti sebagai perbuatan melawan hukum, tetapi secara materil terbukti sebagai perbuatan yang wederrechtelijk. Sifat melawan hukum materil dipergunakan bagi penjatuhan pidana terhadap pelakunya, walaupun hal ini pada akhirnya meninggalkan asas legalitas. Penerapan fungsi positif dari sifat melawan hukum materil ini memang tidak diberlakukan secara umum, tetapi atas dasar kondisif, situasif dan kasuistik sifatnya² ${ }^{2}$.

Beberapa putusan Mahkamah Agung RI yang menganut pergeseran ke arah fungsi positif dari perbuatan melawan hukum materil, antara lain:

1. Putusan Mahkamah Agung RI No. $275 \mathrm{~K} / \mathrm{Pid} / 1983$, tanggal 29 desember 1983 dalam perkara Drs. R.S. Natalegawa (Direktur Bank Bumi Daya).

2. Putusan Mahkamah Agung RI No. $2477 \mathrm{~K} / \mathrm{Pid} / 1988$, tanggal 23 Juli 1993 dalam perkara PT. Metro Sakti.

3. Putusan Mahkamah Agung RI No. $1571 \mathrm{~K} / \mathrm{Pid} / 1993$, tanggal 18 Januari 1995 dalam perkara Elia Suselo Sosroloka.

2. Memperkaya diri sendiri atau orang lain atau korporasi

Istilah memperkaya diri sebagai istilah dalam unsur delik Undang Undang Nomor 3 Tahun 1971 sebenarnya berasal dari Undang-

${ }^{2}$ Indriyanto Seno Adji, Korupsi dan Hukum Pidana (Jakarta: Kantor Pengacara dan Konsultan Hukum Prof. Oemar Seno Adji dan Rekan, 2001), hal. 180-181. 
undang Tindak Pidana Korupsi terdahulu (Undang-undang No. 24 Prp Tahun 1960). Akan tetapi, undang-undang ini tidak menjelaskan apa yang dimaksud dengan istilah memperkaya itu.

Terhadap unsur memperkaya jelas merupakan delik materil. Konsekuensinya harus dibuktikan seberapa jumlah uang atau aset yang telah terdakwa peroleh dengan delik itu. Sebenarnya, ada kaitan antara pasal 2 dan pasal 37 ayat (4) yang menyatakan kekayaan yang tidak seimbang dengan penghasilannya atau sumber penambahan kekayaannya, maka keterangan tersebut dapat digunakan untuk memperkuat alat bukti yang sudah ada, bahwa terdakwa telah melakukan tindak pidana korupsi.

\section{Dapat merugikan keuangan negara}

Unsur dapat merugikan keuangan negara memang merupakan delik formil, artinya tidak perlu telah terjadi kerugian keuangan atau perekonomian Negara. Kendati begitu, menurut Andi Hamzah, tetap harus dibuktikan dapatnya negara rugi. Jadi, harus dipanggil ahli akuntan untuk menilai menurut perhitungannya, dapatkah negara rugi. Andi Hamzah menilai berlebihan terhadap penafsiran yang mengatakan bahwa dapat merugikan keuangan negara adalah potensial merugikan keuangan negara. Alasannya, kata potensial itu luas sekali artinya. Misalnya, semua orang potensial melakukan kejahatan, sedangkan yang melakukan kejahatan hanya minoritas dari rakyat. Jadi menurut Andi Hamzah, terlampau luas jika kata dapat diartikan potensial. Mestinya tetap ada perhitungan oleh akuntan mengenai dapatnya negara rugi. ${ }^{3}$

Pasal 3 Undang Undang Nomor 31 Tahun 1999 (pasal 1 ayat (1) sub b Undang Undang Nomor 3 Tahun 1971, mengandung unsur sebagai berikut :

1. Dengan tujuan menguntungkan diri sendiri atau orang lain atau korporasi;

'Andi Hamzah, SH, Mergkeritisi Dakmaan Jakesa dan Putusan Hakim Yang Kontraversial, Makalah pada Seminar Perkembangan Penegakan Hukum Terkini, Hotel Bumi Karsa Bidakara, tanggal 5-6 April 2006, hal. 6. 
2. Menyalahgunakan kewenangan, kesempatan atau sarana yang ada padanya karena jabatan atau kedudukan;

3. Dapat merugikan keuangan negara atau perekonomian negara.

Jika dilihat secara seksama, jelas sekali rumusan delik ini berbeda dengan yang tercantum dalam pasal 2 Undang Undang Nomor 31 Tahun 1999, yaitu tidak ada unsur melawan bukum. Jadi tidak perlu dicantumkan dalam dakwaan, dan tidak perlu dibuktikan. Sedangkan adanya pernyataan "dengan tujuan menguntungkan diri sendiri" harus tercantum dalam dakwsan dan harus dibuktikan. Berhubung dengan adanya ungkapan "dengan tujuan" berarti delik ini harus dilakukan dengan sengaja, bahkan sengaja tingkat pertama yaitu sengaja sebagai maksud (opret als oogmerk).

Meskipun tidak secara tegas tercantum adanya unsur melawan hukum dalam rumsan pasal 3 tersebut, akan tetapi sifat melawan hukum itu tetap ada secara diam-diam atau tersirat, sebab tiap delik selalu ada sifat melawan hukumnya, apakah itu sebagai unsur yang tercantum secara tegas ataukah sebagai unsur diam-diam.

Kemudian, adanya unsur "menyalahgunakan kewenangan, kesempatan atau sarana yang ada padanya, karena jabatan atau kedudukan" menunjukkan bahwa delik ini mensyaratkan adanya pelaku delik yang harus mempunyai jabatan atau kedudukan yang disalahgunakan.

Istilah "jabatan" konotasinya berarti dapat dipegang oleh pegawai negeri sipil atau pejabat tetapi tidak oleh orang swasta, namun dengan adanya tambahan ungkapan "atau kedudukan", maka subyek delik pasal 3 terbuka kemungkinan bagi non-pegawai negeri sipil (orang swasta), sebab tidak hanya pegawai negeri sipil yang mempunyai kedudukan, misalnya direktur bank swasta juga mempunyai kedudukan. ${ }^{4}$

4 Sudarto, Hukum dan Hukum Pidana (Bandung: Alumni, 1977), hal. 165 - 166 
Mencermati unsur kedua tersebut, Mahkamah Agung RI dalamperkara Ir. Akbar Tandjung telah membebaskan terdakwa Dadang perkara Ir. Akbar Tandjung telah membebaskan terdakwa Dadang Sukandar dan terdakwa Winfried Simatupang dari dakwaan pasal 1 ayat (1) sub b Undang Undang Nomor 3 Tahun 1971 (sama dengan pasal 3) karena kedua terdakwa itu adalah swasta murni yang tidak mempunyai jabatan yang dapat disalahgunakan.

\section{Penutup}

Hal-hal yang sangat mendasar untuk diperhatikan dalam penegakan hukum memberantas korupsi adalah tekad dan komitmen terhadap perbuatan korupsi sebagai musuh yang harus diberantas. Selain itu, sebagai penegak hukum dan keadilan, hendaknya menjaga integritas moral dalam melaksanakan tugas dan fungsi peradilan untuk menegakkan hukum, kebenaran dan keadilan. Bagaimanapun baiknya perangkat hukum dan sistem yang ada, jika aparat penegak hukumnya tidak memiliki integritas moral yang tinggi, maka niscaya apa yang kita harapkan tidak akan tercapai.

Peningkatan profesionalisme dengan penguasaan ilmu pengetahuan hukum dan asas-asas hukum dan perundang-undang yang berlaku merupakan faktor yang amat menentukan dalam melaksanakan tugas peradilan, dan yang tidak kurang pentingnya pula adalah memperbanyak pengalaman, pendalaman, dan pengamatan terhadap praktek peradilan itu sendiri.

Pemerintah perlu membenahi peraturan perundang-undangan nasional yang berkaitan dengan pemberantasan korupsi yang didukung juga dengan sistem administrasi pemerintah yang memadai. Kebijakan pemerintah dalam pemberantasan korupsi harus diperkuat dengan kebijakan hukum dan kebijakan keuangan negara serta diikuti partisipasi dan tanggung jawab sosial dari seluruh lapisan masyarakat, khususnya LSM dan para anggota DPR/DPRD. 


\section{DAFTAR PUSTAKA}

Adji, Indriyanto Seno. "Korupsi dan Hukum Pidana." Kantor Pengacara dan Konsultan Hukum Prof. Oemar Seno Adji dan Rekan, Jakarta, 2001.

Hamzah, Andi. Pemberantasan Korupsi melalui Hukum Pidana Nasional dan Internasional. Jakarta: PT. Raja Grafindo Persada, 2004.

- "Mengkritisi Dakwaan Jaksa dan Putusan Hakim Yang Kontroversial," makalah pada Seminar Perkembangan Penegakan Hukum Terkini, Hotel Bumi Karsa Bidakara, tanggal 5-6 April 2006.

Sudarto. Hukum dan Hukum Pidana. Bandung: Alumni, 1977. 